\title{
THE PERCEPTION OF INVESTORS TOWARDS INITIAL PUBLIC OFFERING: EVIDENCE OF NEPAL
}

\author{
Achut Gnawali ${ }^{1)}$, Ballav Niroula ${ }^{2)}$ \\ tu_mgmt@hotmail.com ${ }^{1)}$, ballavsir@gmail.com ${ }^{2)}$ \\ Central Department of Management, Tribhuvan University ${ }^{1)}$, \\ Patan Multiple Campus, Tribhuvan University ${ }^{2)}$
}

\begin{abstract}
The main aim of this study is to examine the perception of investors towards initial public offering (IPO), to analyze the relationship between different factors (quality management, company goodwill, company performance, company sector and market information) and investment decision to examine the factors that impact in IPO to making investment decision. This research used primary data. The data was collected from 290 respondents which was related to five different brokerage firms at Kathmandu district. The inferential analysis was preferred in SPSS by using statistical tools such as correlation and regression analysis to analyze the relationship between variables and the impact of different factors on investment decision. The study revealed that quality management, company goodwill, company performance, company sector and market information are the highly considerable factors before making investment decision in IPO.
\end{abstract}

Keywords: Investors, Initial Public Offering, Perceptions, Financial Market

\section{INTRODUCTION}

The selling of business shares to the public for the first time is an initial public offering (IPO). Generally, the main aim of Initial Public offering (IPO) to raise the capital. Generally, companies generating beginning capital through personal loan, equity, family and friends. The financial market provides a platform to buyers and sellers, to meet and trade assets at a price determined by the demand and supply forces. Financial market is broadly classified into two types on the basis of maturity - money market and capital market. It is divided in to two types - primary market and secondary market. Primary market is a financial market where company is listed on an exchange, for the first time, issues new security, or listed companies bring fresh issues (financialjargon.com).

Any private company can go public by selling their stocks to general public through IPO process. It can age of company like old, new or young company that decided to be listed in the stock exchange and go public. All the traded stocks are listed in NEPSE in Nepal. Company raising money through IPO is called 'company going public'. When a company offers stocks to the public, then each stock represents a piece of ownership of the company. And each investor who holds stocks of the company will be considered a part of the owners of the company. When a company performs well, its investors get rewarded in the form of increased value of their stock. The risk comes, when a company is not doing well, and its stock value is on the fall. Investment decision in any avenue is an outcome of some analyses. It may be both fundamental analysis and technical analysis. IPO issues provide an opportunity to maximize return as they penetrate into equity investments. (www.invetopedia.com).

Khatri (2017) stated that the reasons of IPO issue are funding needs and nonfinancing requirements, financing capital necessities for gradually increase, develop by projects, expansion, financing inclusive necessities, financing needs for joint-ventures, financing requirements for infrastructure, marketing campaigns and distribution networks, 
financing requirements for working capital, financing general corporate purposes, investing in undertakings through other firms.

The IPO application process in Nepal is now on digital and thus everything is completed online and no longer require bank visits. Applying for the IPOs of Nepal can be done through laptop or even a smartphone or tablet. The selling normally takes place for four working days and during those four days you have to go to the website of Meroshare, login and fill in all the information of the Application Sponsored by Blocked Sum (ASBA) and submit it. Make sure that the bank account has the sum of rupees required for ASBA to be blocked. Within a week of submission, the allotment will be concluded. The public can also apply the shares directly visiting the on which they have bank account. On primary shares at least 10 shares or more divisible by 10 can be applied. After that, the investors are allotted a certain number of shares, based on the number of shares distributed, the number of total applications received and the amount of investment. Each accurate application/applicant has earned at least 10 units of IPO shares since Shrawan 2074. However, investors could obtain additional shares, depending on the number of applicants, if there are more to be distributed or no shares if there are not enough available. The financial organization would release the blocked amount after allocation while debiting the allocated share amount from the bank account of the investor. The share quantity allocated to investors will appear in their DEMAT account statement after some time, (unicodnepali.com).

Sarin \& Sidana, (2018) studied on the most outstanding concern for a company is perceived to be the initial public offering. If a business is just as critical as "going public," "being public." Small and new business owners issue IPOs when they need money, but often large businesses even issue them for public trade. It was considered a major commitment by the organization to go public. This IPO process is going to influence the company's way of doing business. But it's very easy to give an IPO and more time is needed for this. As of May 1, 2007, SEBI made it mandatory for the Indian stock market regulator that all IPOs be rated by a credit rating agency. But it was made optional by SEB within a very short period of time. It is attempted in this paper to discover investor expectations of IPO grading. This research is focused on primary data collected from 200 investors from Delhi and Chandigarh through a well-crafted standardized questionnaire. This research try to analyze the relationship and show the effects between different factors (quality management, company goodwill, company performance, and company sector and market information) and investment decision of investors.

\section{LITERATURE REVIEW}

Craig (2000) studied about IPO market share of investment banks, the researcher analyzed the factors that acting as book managers in IPO and the impact of share of investment banks during 1984 to 1995. The findings shows that at the first day the returns of IPO, one-year complications, not normal compensation, industry concentration, popularity of the predictor and the relation with inhibited and their impact on changes in market share for establish banks.

Bennet et al. (2011) investigated on the attitude of investors on stock selection decisions was studied to investigate the analysis of investors and the factors influencing the decision to pick equity stocks. The sample size of that research includes 400 retail investors scattered across ten different Investment Centers. This study try to emphasis that the variables; return on equity, quality of management, return on investment and price-to- 
earnings ratio and other different ratios of the business, are influenced by the decisionmakers. It shows that social responsibility given the lowest priority.

Leila and Farshid (2014) focus on "Tehran Stock Exchange" analysis of factors influencing the Initial Public Offering (IPO). It shows that Tehran stock exchange is lower than real price of the initial offering exchange. This research include 115 stock listed companies from 2006-2012. The finding concluded that $\mathrm{P} / \mathrm{E}$ variable has significant relation with price changes on initial offering and it shows that it had highest impact in price on initial offerings.

Singh (2012) carried a study intended to determine the perception of investors towards IPO. The study illustrate about that during of investing in IPO the investors also consider some important factors; images of corporate, corporate size, the company previous IPO performance, current price and current market condition. It is concluded that most of investors invest based on growths and their profit while those in lowest investment bracket base their decisions on growth.

Kunwar (2016) studied about the awareness, perception, and investment decision of individual investors towards IPO in Nepal and to investigate the factors that affects investment decision on IPO. The study used descriptive and inferential analysis. The study used the primary data from 116 respondents. The study found that there was a positive perception of investors towards IPO in Nepal. The study also revealed that awareness level of investor was well above the needed level and the perception of investor towards IPO and awareness level of investor is indifferent based on their gender, age, occupation and monthly income.

Adhikari (2017), made an attempt to identify the factor influencing individual investor's behavior during IPO in Nepal. The basic purpose of the study is to analyze and examine the investor's perception and factors that influence individual investor behavior during IPOs in Nepal. In this study exploratory and descriptive research design was used. The data used primary data and it was collected through questionnaire from 100 respondents. The study found out that capital appreciation, investors demographics trends, preferred source of information, and industry specialization are the most important factors before making investment decision in IPO. Adoption of interest, social media, mobile marketing and awareness program will enhance the public knowledge on IPO and investment at the stock exchange.

Srinivas and Rao (2017) attempted to find out the factors influencing investment decision in IPO among retail individual investors. The study shows that capital appreciation and safety in investment are the driving forces of the investment. Higher annual returns are also motivating investors towards investment in IPO. Most of the respondents are investing their funds for a very short period of time (i.e. less than 3 months). They are subscribing shares in primary market through IPO and are selling in secondary market for higher return. Long term investment reduces risk and increase return so investors should invest for long time.

\section{RESEARCH METHOD}

This research study attempts to analyze the attitude of investors towards IPO in Nepal. To conduct the study, two types of approach were adopted, descriptive and explanatory research design. The target population for this study includes all the investors who invested in IPO in Kathmandu District. As a result, the researcher selected 320 investors to represent the population. Although questionnaires were distributed to all 320 sample respondents, only 290 of them responded. The response rate was $90.63 \%$. Kunwar 
(2016) in his study on the awareness, perception and investment decision of individual investor towards IPO. That study used 232 samples of investors as investors of individual country. This study used convenience sampling method to collect data from the respondents. It is because the researcher has convenient accessibility of data and proximity where five major brokerage firms located in Kathmandu were visited to find the respondents which would represent the investors of the country. Furthermore, convenience sampling is ideal when dealing with very large population. The data for research was collected with the help of a questionnaire based on a 5-point rating scale ranging from 1very high consider to 5-very low consider.

Thirty-two opinion statements were set to measure six different variables among which, five are independent variables, and one is dependent variable. Twenty-eight different opinion statements were used to describe independent variables namely "quality management", "company goodwill", “company performance", "company sector" and "market information". Four different opinion statements described dependent variable which is "investment decision". The study is based on primary data since it provides relevant and current data in the subject of study. Structured questionnaires were distributed to investors of five brokerage firms inside Kathmandu valley. The data were collected during five days from the respondent. Responses on the questionnaire were collected within a period of five days in the month of January 2020.

Using statistical tools, the data collected from the questionnaire was analyzed and the results were presented. The analysis begins with the study of primary data using the SPSS. The data obtained from the respondents was coded into the SPSS version 23 worksheet and tabulated. To test the reliability of scaled products, the alpha coefficient of Cronbach Alpha was used. Regression, correlation and hypothesis have been used for inferential analysis. The Alpha coefficient of Cronbach is less than 0.6. Generally, the value is above 0.6 and below 0.8 consider acceptable and if the value if above 0.8 it is consider as strong (Sekaran, 2000). Here, Cronbach's Alpha of all variable is between 0.6 to 0.8 and above, hence, all variables are acceptable. Therefore, the instruments used in this research are considered to be reliable.

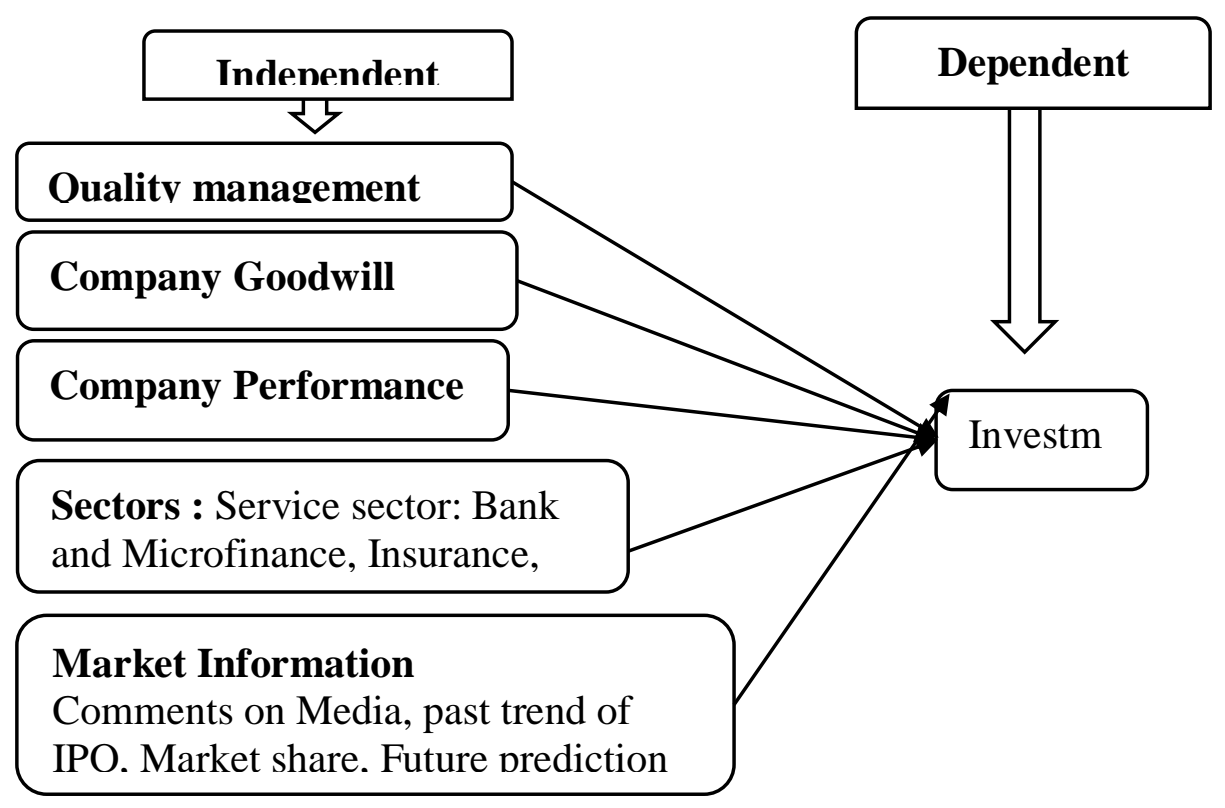

Figure 1. The Conceptual framework 
This study consist five independent variables; quality management, company goodwill, company performance, and company sector and market information. Meanwhile, it has one dependent variable which is the research investment decision. This conceptual framework illustrated by in previous study Craig (2000), Leila B and Farshid (2014), Singh (2012), Kunwar (2016), Adhikari (2017), and Srinivas and Rao (2017).

\section{Hypotheses}

The following hypotheses are formulated for this study.

H1: There is positive relationship between quality management and investment decision.

$\mathrm{H} 2$ : There is positive relationship between company goodwill and investment decision.

H3: There is positive relationship between company performance and investment decision.

$\mathrm{H} 4$ : There is positive relationship between company sector and investment decision.

H5: There is positive relationship between market information and investment decision.

\section{RESULT AND DISCUSSION}

The analysis results produced from the data collection process are presented in this chapter. This research used primary data and the data obtained via questionnaire and used 290 respondents for it. As stated in the previous section, data was analyzed with reference to the objectives of this study. This chapter represent to analyze the data and represent the results that derived from analysis of the data.

\section{Demographic Data}

The respondents' profile is shown in the following table:

Table 1. The Distribution of Respondents' Profile

\begin{tabular}{clcc}
\hline \multirow{2}{*}{ Age } & Profile & Frequency & Percentage \\
& Below 25 & 40 & 13.8 \\
& $25-40$ & 158 & 54.5 \\
& $41-55$ & 82 & 28.3 \\
& Above 55 & 10 & 3.4 \\
& Total & $\mathbf{2 9 0}$ & $\mathbf{1 0 0}$ \\
Gender & Male & 160 & 55.2 \\
& Female & 130 & 44.8 \\
& Total & $\mathbf{2 9 0}$ & $\mathbf{1 0 0}$ \\
& SLC & 18 & 6.2 \\
& Intermediate & 42 & 14.5 \\
& Bachelor & 128 & 44.1 \\
& Master level or above & 102 & 35.2 \\
Occupation & Total & $\mathbf{2 9 0}$ & $\mathbf{1 0 0}$ \\
& Business & 8 & 2.8 \\
& Investor & 136 & 46.9 \\
& Farmer & 8 & 2.8 \\
& Service & 64 & 22.1 \\
& Student & 74 & 25.4 \\
Investment amount in IPO & Total & $\mathbf{2 9 0}$ & $\mathbf{1 0 0}$ \\
(currency here) & 1-10 thousand & 170 & 58.62 \\
& 10-50 thousand & 70 & 24.14 \\
& 50-100 thousand & 38 & 13.10 \\
& 1 lakh and above & 12 & 4.14 \\
& Total & $\mathbf{2 9 0}$ & $\mathbf{1 0 0}$ \\
\hline
\end{tabular}

Source: Field Survey, 2020 
Table 1 shows that $13.8 \%$ of the respondents are of the age group of below 25 years and they are between 25-40 year and the respondents were 54.5\%. Similarly, out of the total respondents, $28.3 \%$ and $3.4 \%$ of the respondents were aged between $41-55$ years and the rest of are above 55 years respectively. It shows that most of the retail investor respondents were in their prime ages, between 25-40 years old, they are in the youth group.

More than one-third (46.9\%) of the respondents had stock investment as their main occupation, $25.5 \%$ respondents were student and $22.1 \%$ respondents had service. Among the total respondents, $2.8 \%$ had business as their main occupation and also $2.8 \%$ were farmers. Majority of the respondents $(58.62 \%)$ had 1-10 thousand invested in IPOs. Among the respondents, those who have invested Rs. 10-50 thousand and 50-100 thousand are $24.14 \%$ and $13.10 \%$ respectively, whereas, only $4.14 \%$ had investment Rs. 1 lakh and above in IPO.

\section{Inferential Statistics}

Inferential statistics are procedures used which allow researchers to infer or generalize observations made with samples to the larger population from which they were selected. This result provide new information through prediction and generalize based on samples.

\section{Correlation analysis}

Correlation between Independent and Dependent variables is shown in Table 2.

Table 2. The Correlation Analysis Results

\begin{tabular}{|c|c|c|}
\hline & & Investment decision \\
\hline Quality management & $\begin{array}{l}\text { Pearson Correlation } \\
\text { Sig. (2-tailed) }\end{array}$ & $\begin{array}{l}.466 * * \\
.000\end{array}$ \\
\hline Company goodwill & $\begin{array}{l}\text { Pearson Correlation } \\
\text { Sig. (2-tailed) }\end{array}$ & $\begin{array}{l}.719 * * \\
.000\end{array}$ \\
\hline Company performance & $\begin{array}{l}\text { Pearson Correlation } \\
\text { Sig. (2-tailed) }\end{array}$ & $\begin{array}{l}.573^{* *} \\
.000\end{array}$ \\
\hline Company sector & $\begin{array}{l}\text { Pearson Correlation } \\
\text { Sig. (2-tailed) }\end{array}$ & $\begin{array}{l}.751^{* *} \\
.000\end{array}$ \\
\hline Market information & $\begin{array}{l}\text { Pearson correlation } \\
\text { Sig.(2-tailed) }\end{array}$ & $\begin{array}{l}.441^{* *} \\
.000\end{array}$ \\
\hline Investment Decision & $\begin{array}{l}\text { Pearson Correlation } \\
\text { Sig. (2-tailed) }\end{array}$ & $\begin{array}{l}1 \\
0.005\end{array}$ \\
\hline
\end{tabular}

$* *$ Correlation is significant at the 0.01 level (2-tailed)

Sources: Field Survey, 2020

Table 2 shows that the Pearson Correlation coefficient between the independent variable quality management, company goodwill, company performance, company sector, market information and dependent variable investment decision is 0.466,0.719, $0.573,0.751$, and 0.441 respectively which implies that the five variables are positively correlated and there is correlation between quality management, company goodwill, company performance, company sector, market information and perception in investment decision. They are significant at $1 \%$ significance level.

\section{Regression Analysis}

Regression analysis presents more details on the slope of the relationship in this situation. It is used to identify a relationship's existence and to make predictions. To 
explore the effect of independent variables, multiple regressions were used (quality management, company goodwill, company performance, company sector, market information) on dependent variable perception in investment decision.

Statistically regression equation can be written as:

$$
\hat{\mathrm{Y}}=\alpha+\beta_{1} X_{1}+\beta_{2} X_{2}+\beta_{3} X_{3}+\beta_{4} X_{4}+\beta_{5} X_{5}+e_{i}
$$

Where,

$\begin{array}{lll}\hat{\mathrm{Y}} & = & \text { Investment decision (dependent variable) } \\ X_{1} & = & \text { Quality Management } \\ X_{2} & = & \text { Company Goodwill } \\ X_{3} & = & \text { Company performance } \\ X_{4} & = & \text { Company Sector } \\ X_{5} & = & \text { Market Information } \\ \alpha & = & \text { Constant } \\ \beta_{1}, \beta_{2} \ldots \beta_{5} & = & \text { Regression coefficients of Factor } 1 \text { to Factor } 5 \text { respectively } \\ \mathrm{e}_{\mathrm{i}} & = & \text { Error term }\end{array}$

Table 3. The Model Summary

\begin{tabular}{lllll}
\hline Model & $\mathbf{R}$ & R Square & Adjusted R & Std. Error of the Estimate \\
\hline $\mathbf{1}$ & $.836^{\mathrm{a}}$ & .698 & .687 & .48407 \\
\hline
\end{tabular}

Predictors: (Constant), Market Information, Company Sector, Company Performance, Quality Management, Company Goodwill.

The model summary of the study indicates the $R^{2}$. R square help to identify coefficient variation that used in regression. The value of $\mathrm{R}^{2}$ value is 0.698 in Table 3 which indicate that the model can explain $69.8 \%$ of independent variables are responsible for investment decision in IPO. However, the remaining $30.2 \%$ is still unexplained in this research. The model of summary table represents standard error and in this study is 0.48407 which shows the variability of the observed value of investment decision.

Table 4. The ANOVA Test Results

\begin{tabular}{lllllll}
\multicolumn{7}{c}{ ANOVA $^{\mathbf{a}}$} \\
\hline & Model & Sum of Squares & df & Mean Square & F & Sig. \\
\hline $\mathbf{1}$ & Regression & 75.402 & 5 & 15.080 & 64.357 & $.000^{\mathrm{b}}$ \\
& $\begin{array}{l}\text { Residual } \\
\text { Total }\end{array}$ & 32.571 & 139 & .234 & & \\
& 107.972 & 144 & & & \\
\hline
\end{tabular}

a. Dependent variable: Investment decision

b. Predictor: (constant), market information, company sector, company performance, quality management, company goodwill.

The ANOVA test shows that the calculated p-value, 0.001, That is lower than the value of alpha 0.01 . The model is therefore a strong predictor of the relationship between the dependent variables and the independent ones. The independent variables, as a result, (quality management, company goodwill, company performance, and company sector and 
market information) are significant in explaining the variance in investment decision in IPO.

Table 5. The Regression Coefficient Analysis Results

\begin{tabular}{|c|c|c|c|c|c|}
\hline \multicolumn{6}{|c|}{ Coefficients $^{\mathrm{a}}$} \\
\hline \multirow[t]{2}{*}{ Model } & \multicolumn{2}{|c|}{$\begin{array}{l}\text { Unstandardized } \\
\text { Coefficients }\end{array}$} & $\begin{array}{l}\text { Standardized } \\
\text { Coefficients }\end{array}$ & $\mathrm{T}$ & Sig. \\
\hline & $\mathrm{B}$ & Std. Error & Beta & & \\
\hline 1 (Constant) & -0.571 & .155 & & -3.675 & .000 \\
\hline Quality Management & .148 & .059 & .135 & 2.530 & .013 \\
\hline Company Goodwill & .337 & .085 & .274 & 3.957 & .000 \\
\hline Company Performance & .205 & .084 & .142 & 2.427 & .017 \\
\hline Company Sector & .487 & .078 & .411 & 6.238 & .000 \\
\hline Market Information & .126 & .062 & .109 & 2.031 & .044 \\
\hline
\end{tabular}

Dependent variable: Investment Decision

The above table shows the findings; the following model has been developed.

$$
\hat{\mathrm{Y}}=-0.671+0.148 X_{1}+0.337 X_{2}+0.205 X_{3}+0.487 X_{4}+0.126 X_{5}
$$

In the regression analysis, the beta coefficients are used to explain the relative importance of the independent variables in contribution to the variance in dependent variable. The results presented in Table 5 , shows that company sector $\left(\beta_{4}=0.487, p=0.000\right)$ carries the heaviest weight for investment decision, followed by quality management $\left(\beta_{1}=0.148, \mathrm{p}=0.013\right)$, company goodwill $\left(\beta_{2}=0.337, \mathrm{p}=0.000\right)$, company performance $\left(\beta_{3}=0.205, \mathrm{p}=0.017\right)$, market information $\left(\beta_{5}=0.126, \mathrm{p}=0.044\right)$. The results show that a one-unit increase in company performance would lead to a 0.205-unit increase in investment decision keeping other variables constant. Similarly, one-unit increase in quality management factor would lead to a 0.148-unit increase in investment decision, one-unit increase in company goodwill factor lead to a 0.337 -unit increase in investment decision and so on. In conclusion, quality management, company goodwill, company performance, company sector and market information dimensions are significant. Thus, the result of multiple regression analysis accepts alternative hypotheses that there is positive relationship between independent variables and dependent variable in investment decision.

\section{Hypothesis Results}

The results of each of these hypotheses are presented below. 
Table 6. The Hypothesis Testing Results

\begin{tabular}{|c|c|c|}
\hline S. $\mathbf{N}$ & Alternative hypothesis & Result \\
\hline H1 & $\begin{array}{l}\text { There is relationship between Quality management and } \\
\text { investment decision. }\end{array}$ & $\begin{array}{l}0.000<0.01, \\
\mathrm{H} 1 \text { is } \\
\text { accepted. }\end{array}$ \\
\hline H2 & $\begin{array}{l}\text { There is relation between Company goodwill and investment } \\
\text { decision. }\end{array}$ & $\begin{array}{l}0.000<0.01 \text {, } \\
\mathrm{H} 2 \\
\text { accepted. }\end{array}$ \\
\hline H3 & $\begin{array}{l}\text { There is relationship between Company performance and } \\
\text { investment decision. }\end{array}$ & $\begin{array}{l}0.000<0.01, \\
\mathrm{H} 3 \quad \text { is } \\
\text { accepted. }\end{array}$ \\
\hline H4 & $\begin{array}{l}\text { There is relationship between Company sector and investment } \\
\text { decision }\end{array}$ & $\begin{array}{l}0.000<0.01 \\
\mathrm{H} 4 \text { is accepted }\end{array}$ \\
\hline H5 & $\begin{array}{l}\text { There is relationship between Market information and } \\
\text { investment decision. }\end{array}$ & $\begin{array}{l}0.000<0.01 \text {, } \\
\text { H5 is } \\
\text { accepted. }\end{array}$ \\
\hline
\end{tabular}

Sources: Field Survey, 2020

Table 6 shows that there exists relationship between each independent variable with dependent variable (investment decision). The correlation is significant at $1 \%$ significance level, as each p-value is less than alpha i.e. $0.000<0.01$. Hence, all hypothesis can be accepted.

\section{CONCLUSION AND SUGGESTIONS}

The objective of this research is to examine the perception of investor towards IPO in Nepal. Five research hypotheses were formulated and tested to identify the impact of five dimensions (quality management, company goodwill, company performance, and company sector and market information) considering investment decision. From the significant value taken from the sample, the significance of the hypothesis among the variable is also evaluated. It embraces all five alternatives. To address the five study hypotheses, the correlation findings were used. The Pearson coefficient of correlation between all five different variables and the dependent variable (investment decision) was done, which implies that five variables (quality management, company goodwill, company performance, company sector and market information) are positively correlated at $1 \%$ significance level. The value of R-square value is 0.698 which means $69.8 \%$ variation in investment decision is explained by the independent variables. However, the remaining $30.2 \%$ is still unexplained in this research.

In IPO, there have been many researches entitled around the world. Many researches were contributed in different dimensions of IPO. Srinivas and Rao (2017) studied the investors attitude towards investment decision in equity market showed that stock market have different attitude towards risk and return, where some investors are risk bearer and some are risk avoider. The risk bearer attitude will be based on personal, economical, environment and situational factors such as income, family size expenditure pattern and age. Similarly, Nagtilak and Kulkarni (2015) conducted the study on investor's perception towards initial public offering in Mumbai revealed that IPO is risk free form of investment where careful research and study needed. Likewise, Vakil's (2018) study of investor's perception about IPO and IPOs performance in stock market found that there exists risk return relationship on the behalf of investing in IPO. Investors invest in IPO due to the 
expected higher return, company profile (i.e. history of company, future expected growth in the form of dividend), earning per share, and price. So the above studies have the same level of contribution and findings as this present study. This research clearly indicates that company goodwill, company performance and market information are major factors which largely affect in perception in investment decision in IPO. Company sector and quality management also are the highly considered factors. This study contributes $69.8 \%$ on the perception in investment decision on IPO. This research is consistent with the above studies.

\section{REFERENCES}

Adhikari, H. C., (2017). "Factor influencing individual investors' behavior during Initial Public Offering (IPO) in Nepal". An unpublished master degree thesis, Central Department of Management, Tribhuvan University.

Banerjee, S. and Bit, J. (2014). Forest conservation in India: An inquiry into economic linkages and long-run sustainability. CBS Journal of Management Practices, 1(2). July-December.

Bennet, E., Selvam, M., Ebenezer, E., Karpagam, V. \&Vanitha, S. (2011). Investors' attitude on stock selection decision, International Journal of Management \& Business Studies, 1(5).

Craig G. D. (2000) - "Factors affecting investment bank initial public offering market share". Journal of Financial 55. http://isiarticles.com/bundles/Article/pre/pdf/13781.pdf

Condrea, P. and Boston, I. (2008). Environmental issues from an economic perspective. Environmental Engineering and Management Journal, 7 (6). pp. 843-849.

Ghosal, S. (2011). Pre-colonial and colonial forest culture in the presidency of Bengal. Journal of Studies and Research in Human Geography, 5 (1), pp.107- 116.

Khatri, N. N. (2017). Factors influencing investors' investment in initial public offering. International Journal of Management and Applied Science, 3 (7).

Kunwar, A., (2016). Awareness, perception and investment decision of individual investors towards Initial Public Offering (IPO). An unpublished master degree thesis, Central Department of Management, Tribhuvan University.

Leila B \& Farshid A. (2014) - "Study of Factors Affecting the Initial Public Offering (IPO) Price of the Shares on the Tehran Stock Exchange." Research in World Economy, Vol. 5, No. 2; 2014

L.Srinivas\& P. V. Rao. (2017). A Study on factors influencing IPO decisions among retail individual investors in Visakhapatnam. International Journal of Research in Economics and Social Sciences (IJRESS), 7 (9), 613-620.

Nagtilak, A., \& Kulkarni, N. (2015). A study on investor's perception towards initial public offering in mumbai. Abhinav National Monthly Referred journal of Research in Commerce and Management,4 (3), 75-86.

Pokharel, P. (2018). A Survey of Investors preference on stock market: A case of Nepal Stock Exchange. Saptagandaki Journal, 9(12), 53-61. https://doi.org/10.3126/sj.v9i0.20880.

Sarin, V., \& Sidana, N. (2018). A Study of Perceptions of Investors Towards IPO Grading in India. November 2017.

Singh, A.K., Maurya, S. and Mohapatra, A.K. (2019). IPO Underpricing and predictive power of board related corporate governance mechanisms: A Study of Indian IPO Market. Theoretical Economics Letters, 9(19).https://doi.org/10.4236/tel.2019.96127 
Singh, J., \&Yadav, P. (2016). Study on the factors influencing investors' decision in investing in equity shares in Jaipur and Moradabad with reference to Gender, Amity Journal of Finance, 1(1).

Singh,M.(2012). Investor's perception on initial public offering (IPO). International Journal of Computing and Business Research, 3 (3), 1-21, 5(2).

Sekaran, U., (2000). Research methods for business: A skill building approach (3rd edition). New York: John Wiley \& Sons.

Vakil, S. (2018). A study of investor's perception about IPO and IPO's performance in stock market. Asia Pacific Journal of Research (APJR).

\section{Websites:}

https://financialjargon.com/

http://ww12.unicodnepali.com/ 